TEOLOGI KEM(U)(A)RAHAN ALLAH

Sebuah Upaya Mengkonstruksikan Teologi Kemurahan Allah

\title{
Hardiyan Triasmoroadi"
}

\begin{abstract}
In the context of identity contestation in today's Indonesia, it is worth putting back the discourse of the "face of God", since it may raise questions such as: "Does the fierce religious expression refer to the theology of the wrath of God? What is the contribution of the theology of mercy in intervening the interreligious dispute? What is the biblical response on the relationship between God's wrath and mercy?" To expose those issues, this article constructs the theology of God's mercy as a basis for a distinct religious behavior presenting the true companionship.
\end{abstract}

Keywords: rectoverso, the wrath of God, the mercifull God, contextual-biblical, constructive theology, beyond binary oppossition.

\section{Abstrak}

Di tengah konteks kontestasi dan pertikaian identitas di Indonesia yang akhir-akhir ini lekat dengan kekerasan, diskursus perihal wajah Allah kembali menarik untuk diketengahkan kembali, sebab secara tak terelakkan memunculkan pertanyaan-pertanyaan: "Apakah di balik laku garang yang diperlihatkan kaum religius terdapat teologi kemarahan Allah? Bagaimanakah kontribusi teologi kemurahan Allah dalam melerai pertikaian interreligius? Bagaimanakah keterkaitan antara gambaran kemarahan Allah dan kemurahan Allah secara biblis?" Dalam rangka mencari jawabnya, maka esai ini akan berupaya mengelaborasi secara

\footnotetext{
* Sekolah Tinggi Teologi (STT) Jakarta. Email: hardiyan.triasmoroadi@gmail.com
} 
biblikal-kontekstual, untuk kemudian mengajukan konstruksi teologi kemurahan Allah sebagai daya dukung yang mendorong laku umat beriman guna semakin menghadirkan kesejatian persaudaraan.

Kata-kata kunci: rectoverso, kemarahan Allah, kemurahan Allah, biblikal-kontekstual, teologi konstruktif, teologi memurahan Allah, oposisi biner, merengkuh.

\section{PENDAHULUAN}

Jika huruf vokal "u" dalam kata "murah", diganti dengan vokal "a", seketika kata "murah" akan menjadi "marah". Membicarakan kemurahan tak bisa dilepaskan dari kemarahan. Marah diartikan Kamus Besar Bahasa Indonesia sebagai ‘sangat tidak senang' (karena dihina, diperlakukan tidak sepantasnya, dan sebagainya), berang, dan gusar. Faktanya, sebagian umat Muslim merasa sangat tidak senang, marah, berang, dan gusar ketika kutipan surah Al Maidah 51 di dalam kitab suci Alquran ditengarai dinista, dihina, dan diperlakukan secara tidak pantas oleh Gubernur Jakarta Basuki Tjahaja Purnama (Ahok). Melalui fatwa Majelis Ulama Indonesia, perasaan gusar dan marah yang membuncah dikanalisasi sehingga menggulirkan serangkaian gelombang demonstrasi protes besar-besaran bertajuk "aksi bela Islam" yang populer disebut "4/11" dan "2/12".

Ketika hendak menuju Surabaya dalam rangka Road Service GKJW pada tanggal 4 November 2016, secara first hand experience, saya menyaksikan dan mendengar sendiri di depan stasiun Gambir, ribuan massa yang serempak menyanyikan koor lagu "menanam jagung” dengan gubahan lirik yang semula "cangkul-cangkul, cangkul yang dalam" menjadi "bunuh, bunuh, bunuh si Ahok... bunuh si Ahok sekarang juga". Sitz im leben yang tak bersahabat, panas, garang, dan lekat dengan amarah tak urung menghamburkan kekuatiran bahwa aksi berpotensi menjadi bola liar yang ditunggangi kaum ekstremis/teroris guna menyulut bara kerusuhan, sebagaimana peristiwa Arab Spring. Apalagi, konteks perjumpaan via media sosial—yang menjadi media efektif bagi penyemaian gerakan perubahan di era teknologi informasi-tensinya turut mendidih, karena baik antara pembela ataupun penghujat Ahok saling melontarkan ujaran kebencian.

Amarah yang tak terkendali berpotensi menyulut pertengkaran, konflik, dan perang. Apalagi, ketika nama Allah digunakan, digemakan berulang kali sebagai justifikasi teologis dan dikonstruksi sebagai semacam ortodoksi atas laku garang, keras, dan intoleran, tentu berdampak bagi ortopraksis 
dan menguatkan semangat militansi-wani mati; berani mati karena berada di jalan yang tepat-jalan ilahi. Saya menduga gambar Allah yang diimajinasikan dalam konteks ini adalah gambar Allah yang marah sambil mengacungkan pedang yang restu-Nya mengarah pada kobaran api peperangan. Demi merespons kegelisahan yang dirasakan di penghujung akhir 2016, maka dalam tulisan ini akan ditelusuri gambar Allah yang pemurah, yang bukan hanya berada di balik wajah Allah yang pemarah, melainkan sejatinya justru hadir melampaui kemarahan-Nya sendiri. Konstruksi gambar Allah yang pemurah kiranya menguatkan upaya penyemaian kedamaian dan rengkuhan terhadap liyan.

Seturut dengan inspirasi Grant R. Osborne, secara metodologis dalam melakukan elaborasi akan digunakan metode multiplex. ${ }^{1}$ Diawali dengan: (1) mendeskripsikan tema-tema individual yang menekankan pada kepelbagaian (diversity), (2) discovering unity atau menemukan kesatuan dinamis tema, dan (3) mengintegrasikan keduanya (diversity+unity). Baik Perjanjian Lama (PL) dan Perjanjian Baru (PB) akan dipilin menjadi kesatuan tematis, mengingat natur interdependensi keduanya yang komplementer. Oleh karena itu, di dalam tulisan ini tidak akan dipisahkan secara rigid antara PL dan PB. Pada gilirannya, hasil riset Alastair V. Campbell dan Peter C. Craigie akan diketengahkan urgensinya dalam turut menuntun dan menerangi keseluruhan struktur.

\section{DESKRIPSI I: MERABA KEPELBAGAIAN LATAR AMARAH}

Secara antropologis, kemarahan manusia dapat dipicu oleh apa yang disebut sebagai "the logic of scarcity." Amos Yong menyebut logika kelangkaan sebagai salah satu simpul yang mendasari letupan bara kekerasan dan perang religius:

"If violence is the result in part of real or perceived scarce resources, and if religion perpetuates this perception through the identification of additional scarcity-wheter of sacred space or land, group privilege, limited access to divine blessing or favor, etc. - then it is understable how religion fuels, rather than resists violence" (Yong, 2008: 140).

Kelangkaan sumber daya bisa mendasari amarah, retaknya relasi, berujung pada perpisahan Abram dan Lot dalam Kejadian 13:1-12, juga memungkinkan terjadinya perang dan kekerasan sebagaimana kisah penaklukan Israel atas Kanaan (Yong, 2008: 141). Apalagi jika dibalut dengan perasaan diperlakukan secara tidak adil, maka amarah dapat melahirkan laku destruktif; layaknya kisah Kain yang membunuh adiknya sendiri, dalam Kejadian 4. Di lain tempat, kisah Ayub memperlihatkan betapa ketidakberdayaan atas sakit, pahitnya kehilangan, dan dahsyatnya penderitaan turut menghadirkan perasaan diperlakukan secara tidak adil oleh Allah, yang menggulirkan protes keras yang diteriakkan Ayub: 


\begin{abstract}
"Murka-Nya menerkam dan memusuhi aku, Ia menggertakkan gigi-Nya terhadap aku... Aku hidup dengan tentram, tetapi Ia menggelisahkan aku. Aku ditangkap-Nya pada tengkukku, lalu dibanting-Nya, dan aku ditegakkan-Nya menjadi sasaran-Nya, Aku dihujani anak panah, ginjalku ditembus-Nya dengan tak kenal belas kasihan, empeduku ditumpahkan-Nya ke tanah, Ia merobek-robek aku, menyerang aku laksana seorang pejuang" (Ayb. 16:9, 12-14).
\end{abstract}

Secara teologis, amarah Tuhan dimungkinkan hadir tatkala terjadi pengkhianatan (betrayal) dan ketidaktaatan (disobedience). Laku manusia sebagaimana dinarasikan dalam kisah pemberontakan (kejatuhan manusia dalam dosa) Kejadian 3 mengundang kesedihan sekaligus kemarahan Allah. Bagaimana tidak, Adam dan Hawa yang semula diciptakan baik, malah memilih untuk menjadi buruk, memberontak, dan mengkhianati perjanjian dengan Allah. Konsekuensinya mereka diusir dari ketentraman Eden.

Melalui perspektif perjanjian, Giovanni mengulas bahwa Yahweh adalah satu-satunya Tuhan yang menyatakan diri-Nya kepada Abraham, Yakub, dan Musa yang melaluinya perjanjian bercorak monoteistik - untuk hanya menyembah kepada Tuhan Allah yang Esa—diikatkan dan dinyatakan. Celakanya, perjanjian diingkari, dikhianati justru "from the very moment that it is concluded, as it shown by the famous episode of Moses breaking the tablets of the law" (Exodus 32). Umat Israel memang berkali-kali menduakan dan mendukakan Tuhan Allah, sehingga Tuhan pun marah (repay-membalas) dan menimpakan kemalangan secara terus-menerus (uninterrupted series of misadventures) yang berkulminasi pada penghancuran Yerusalam pada 586 SM (Giovani, 1988: 52). Di dalam konteks keterpurukan, ketika Israel telah diserakkan dan diserahkan ke tangan bangsa asing sekalipun, Tuhan toh tetap menghakimi dan menghukum sisa-sisa Israel di Yerusalem yang alih-alih bertobat, malah menepuk dada dan mengklaim diri secara superior sebagai umat yang dibenarkan, sembari menuding saudaranya sebagai sesat, sebagaimana Yehezkiel 11:11 yang mewartakan hukuman terhadap Yerusalem. Kebengisan murka-Nya tanpa ampun menghabisi umat-hingga Campbell menyematkan julukan tentatif "God as demon and tempter/agent provocateour, "ketika Tuhan mengubur-membakar hidup-hidup (Bil. 16:31-35), menimpakan tulah (Bil. 11:33), mematikan kesuburan tanah, menghentikan hujan, serta mengkondisikan kelaparan (U1. 11:17).

Dalam PB, Yesus Kristus pun kerap tercatat melontarkan amarah, walau tidak semua Injil sinoptik mengulasnya. Dalam Matius 8:33, Yesus diperlihatkan tidak sabar dan memarahi Petrus yang salah memahami Yesus. Di dalam Markus 3:1-6, Yesus berduka dan berang karena orang banyak yang gagal paham dalam mengerti kesejatian makna sabat, walaupun, Campbell mencatat, bahwa dalam kisah pararelnya, Injil Matius ternyata sama sekali menghilangkan kemarahan Yesus dan Lukas malah mentrasfernya ke orang Farisi (Campbel, 1986: 46). 
Yesus juga memperlihatkan amarah tatkala para murid menghalangi anak-anak kecil untuk datang kepada-Nya (Mrk. 10:13-16), Yesus mengecam Herodes dan menyebutnya sebagai serigala (Luk. 13:32), melontarkan makian "ular beludak", "kuburan yang dilabur putih", dan "orang munafik" kepada orang Farisi (Mat. 23:27, 33), Yesus murka, membuat cambuk dari tali, dan menghamburkan uang penukar ke tanah serta menjungkirbalikkan meja pedagang-pedagang di Bait Suci (Yoh. 2:13-22). Mengutuk pohon ara yang tidak berbuah, serta dengan marah menuding penyesat anak kecil dan menganggapnya lebih baik jika ditenggelamkan ke laut (Mat. 18:6), serta menunjukkan murka Allah bagi mereka yang bertindak secara tidak benar dengan ungkapan berkonotasi sadis: "cungkil mata", "potong dan buang tangan” (Mat. 5:27-30).

Dapat disimpulkan, bahwa secara antroposentris manusia menjadi marah, berang, dan gusar kepada Allah ketika dirinya frustasi dengan kondisi kelangkaan sumber daya, serta merasa diperlakukan tidak adil. Dari perspektif teosentris, amarah Allah tertuju bagi umat, sekaligus bagi musuh umat yang berdosa, memberontak, berkhianat, serta sengaja berpaling atau enggan memahami maksud dan kehendak-Nya.

\section{DESKRIPSI II: KONTRAS ANTARA PL DAN PB?}

Secara tradisional, C.H. Dodd dan A.T. Hanson mendeskripsikan gambar Allah di dalam Alkitab secara kontras. Imaji Allah PL adalah sosok pemarah, bengis, dan gelap, sementara wajah Allah di dalam PB dilukiskan sebagai pemurah, baik, dan terang (Campbell, 1986: 6). Padahal, belum tentu benar, sebab deskripsi semacam ini tentu mengandung konsekuensi yang akan diuraikan berikut.

Di dalam PL, deskripsi “God as Warrior” atau Yahweh Tzevaoth tampak diperlihatkan secara gamblang. Craigie menunjukkan bahwa dalam kisah Ulangan 20:10-18, Allah menjadi dalang yang memerintahkan umat Israel untuk membunuh musuh. Keluaran 15:21 memperlihatkan Allah yang membinasakan bala tentara Mesir. Hakim-hakim 5:31 menunjukkan Allah yang pilih kasih; memberikan kemenangan bagi umat yang dikasihi-Nya serta sebaliknya, memberikan malapetaka bagi musuh-musuh. Allah juga menjadi konsultan perang Israel (Hak. 1:1; 20:18), dan ketika kemenangan diperoleh, rampasan perang didedikasikan untuk-Nya (1 Sam. 15), sehingga melalui proklamasi "Yahweh, TUHAN itu pahlawan perang, TUHAN itulah nama-Nya" (Kel. 15:3), dan “TUHAN, perkasa dalam peperangan!”(Mzm. 24:8), semakin menumbuhkan keyakinan bahwa Allah Sang Perkasa yang jaya dalam peperangan, senantiasa bersama setiap mereka yang mengobarkan peperangan sekaligus memenangkan mereka (Craigie, 1981: 33). 
Secara diametral, di dalam PB, Injil Lukas 6:27-36 justru mengajarkan tentang mengasihi musuh dan berdoa bagi yang menganiaya dengan membalik logika jus talionis-mata ganti mata, gigi ganti gigi: "Siapapun yang menampar pipi kananmu berikan juga pipi kirimu.” Dalam kotbah Yesus di bukit, diajarkan bahwa setiap orang yang marah terhadap saudaranya harus dihukum, karena marah agaknya disejajarkan dengan membunuh (Mat. 5:21-22). Kesemuanya perlu dilakukan secara sempurna, sama seperti Bapa di surga yang adalah sempurna (Mat. 5:48), yang menerbitkan matahari dan menurunkan hujan, baik di kepala orang baik dan jahat, orang benar dan salah. Apalagi jika mengingat peristiwa salib; Sang Kristus mengosongkan diri, menerima amarah, terpuruk dalam bengisnya kekerasan, serta teraniaya sebagai korban karena cintaNya yang diabdikan demi menyelamatkan ciptaan, yang pada gilirannya mendasari surat yang dikirim kepada pelbagai jemaat oleh Paulus dan para rasul. Pengikut Kristus dipanggil guna mengenakan kualitas manusia baru (Ef. 4:24, Kol. 3:10), menghadirkan buah-buah Roh (Gal. 5:22), dan secara tekun menghadirkan kasih persaudaraan (2 Ptr. 1:3-7). Demikianlah terjadi kontras antara wajah Allah yang pemarah dan wajah Allah yang pemurah.

Pertanyaannya adalah, apakah separasi yang mengkontraskan deskripsi atau gambar Allah pemarah di dalam PL, dan Allah pemurah di dalam PB dapat dibenarkan dan sahih? Bukankah jika digali lebih lanjut, gambar kemarahan Allah sebenarnya tidak hanya terdapat dalam PL, dan sebaliknya, gambar kemurahan Allah tidak hanya terdapat dalam PB, melainkan keduanya berpilinan menjalin kesatuan kompleks dalam keseluruhan Alkitab?

\section{MENEMUKAN KESATUAN: MELAMPAUI RECTOVERSO M(U)(A)RAH}

Demi merespon kontras yang seolah terdapat di antara PL dan PB, secara menarik Alastair Campbell, juga Peter C. Craigie memetakan tiga respon tipe yang kerap kali diketengahkan sebagai solusi.

Tipe solusi pertama. Menolak gambar kemarahan Allah. Beberapa bagian primitif yang menggambarkan watak partisipasi Allah PL yang keras dan vulgar dianggap tidak layak sehingga harus dipisahkan dan ditolak dari kanon (Campbell, 1986: 5-6). Penolakan ini dicatat pertama kali muncul dalam pandangan Marcion di abad kedua Masehi, yang disebut Craigie berangkat dari tesis bahwa gagasan Allah sebagai panglima perang tak lebih dari sekadar interpretasi manusia, dan bukan penyataan dari aktivitas serta natur alamiah Allah pada dirinya sendiri (Craigie, 1981: 34-37). Menurut Craigie terdapat bahaya dari penolakan semacam ini, karena berarti menegaskan diskontinyuitas dan menegasikan PL "as a revelation". Artinya PL berhenti menjadi sekadar kumpulan kitab yang tidak mengandung penyataan atau penyingkapan Allah. Padahal menurut 
Craigie, di dalam PB, khususnya Kisah Para Rasul 7:35-36, 13:17, Paulus dan Stefanus tidak pernah menolak gagasan Allah sebagai "God as Warrior”, Sang Pahlawan perang yang telah membebaskan Israel dari tanah perbudakan Mesir. Karena itu, Craigie hendak melampauinya dan menyarankan interpretasi yang jauh lebih positif dengan mengajak untuk memahami konsep "God as Warrior" dari perspektif keniscayaan penyataan ilahi (Craigie, 1981: 38).

Craigie menjelaskan bahwa Allah menyatakan diri melalui sabda dan partisipasi langsung yang menyejarah. Pembacaan terhadap gagasan "God as Warrior” harus diletakkan dalam konteks partisipasi Allah Transenden yang menjadi imanen dalam rangka menyelamatkan ciptaan. Di sini, Allah berpartisipasi melalui cara dan bentuk normal sebagaimana aktivitas keseharian insani: “God as Warrior, of his fought through the fighting people," di tengah realitas kekerasan dan perang yang merupakan keniscayaan dari natur evil dan keberdosaan kemanusiaan. Akibatnya, sebagaimana juga digarisbawahi juga oleh Yonky Karman dalam bunga rampainya, keterlibatan Allah di dalam perang, lebih disebabkan pertimbangan bahwa hal tersebut merupakan bagian dari proses keterlibatan-Nya dalam sejarah umat dan bukan sebagai pembenaran atas perang an sich, mengingat larangan jangan membunuh tetaplah berlaku (Karman, 2007: 159; Craigie, 1981: 38-40).

Solusi tipe kedua, menginterpretasikan kemarahan dan kemurahan secara koheren. Artinya kemarahan Allah dilihat dalam keterkaitannya dengan tujuan kekudusan (God's holiness). Dalam pandangan ini, ditegaskan natur enigmatik Allah yang berada dalam ketegangan antara amarah dan cinta kasih, menuju pada upaya pengudusan. Singkatnya, yang berdosa dan cemar mendapatkan amarah ilahi, supaya dapat bertobat dan kembali kudus. Selain Barth, Leon Morris disebut Campbell sebagai sosok yang menggunakan konsep kekudusan untuk menjelaskan kemarahan Allah: "A Holy God wills to pour out the vials of His wrath upon those who commit sin." Namun Campbell mengkritik Morris dengan menyatakan bahwa konsep kekudusan yang digunakan untuk menjelaskan kemarahan Allah tidak dapat secara memuaskan menjelaskan natur "God's anger in wayward, spasmodic, or unpredictable." Campbell mencontohkan tidak mudah menemukan alasan dan begitu saja mengaitkan kekudusan ilahi di dalam kisah murka Tuhan terhadap Musatatkala tiba-tiba secara tak terduga Allah berikhtiar untuk membunuhnya (Kel. 4:24), demikian pula tidak gampang menafsirkan Allah yang membunuh Uza dalam 2 Samuel 6:7 gara-gara lembu penarik tergelincir dan Uza menyentuh tabut Allah yang kudus itu (Campbell, 1986: 7-8).

Solusi tipe ketiga, menyarankan untuk melihat kemarahan Allah dalam perspektif "passionate seeking for human-well-being" yang mengkarakterisasikan cinta-kasih dan kemurahan ilahi. Yang menarik dari solusi ini adalah upaya menempatkan sentralitas cinta kasih atau kemurahan Allah dalam relasinya dengan aspek kemanusiaan, yang pada saat yang sama tidak berpretensi untuk mengabaikan aspek kemarahan Allah. Sebagaimana The Crucified God, 
karya Moltmann yang dikutip Campbell, "love is experienced not only as peacefull creativeness but as violent breakthrough.” Kemarahan Allah harus dilihat sebagai perluasan dari kemurahan atau cinta-Nya yang terluka. Disebabkan oleh passion yang besar terhadap manusia, Allah pun menderita. Dus, kemarahan adalah tuturan luka Allah karena cinta-Nya yang merindukan manusia, dan kemarahan bukanlah berkebalikan dari kemurahan, sebab kebalikan dari kemurahan cinta adalah indifference atau ketidakpedulian (Moltmann dalam Campbell, 1986: 8-10).

Penjelasan Campbell dan Craigie berharga dan membantu menyediakan konteks yang lebih luas untuk memahami masalah. Saya sepakat dengan solusi tipe ketiga yang memadai guna dipakai menegaskan gambar Allah yang pemurah, yang bukan hanya sekadar berada secara terbatas di balik wajah Allah yang pemarah — sebagaimana ilustrasi rectoverso; dua wajah berbeda yang saling bertolak belakang dalam satu koin yang sama-melainkan, kemurahan-Nya justru melampaui dan mengatasi kemarahan-Nya.

\section{INTEGRASI: "SUPAYA MEREKA SEMUA MENJADI SATU"}

Kemarahan Allah yang membumihanguskan kehidupan, disebabkan kerusakan yang dibuat manusia akibat pengkhianatan dan pemberontakan. Ketika manusia selaku ciptaan, menolak dan memalingkan diri dari Sang Pencipta, maka serta merta manusia menjadi berdosa dan berada dalam kegelapan (Countryman, 1987: 108).

Diterangi oleh "salvificlove", demimendandanikosmos supaya semakin apik dan konstruktif, maka digemakanlah seruan pertobatan, supaya manusia berbalik kembali kepada Sang Terang (Mat. 3:7, Luk. 3:7), dan laku dekonstruksi (destruksi) dinyatakan bagi mereka yang menyimpang (Zef. 1:18, Yl. 1:15). Di tengah keberdosaan dunia, Allah bersedia menjadi rentan, menyejarah selaku "warrior" yang berperang demi membela umat-Nya sembari melontarkan amarah atas ketidakadilan, penindasan, dan ketidaktaatan. Karya Allah yang menyejarah memuncak pada inkarnasi-Nya dalam Yesus Kristus (Fil. 2:6-8).

Pengorbanan diri Kristus Yesus di kayu salib yang ditegaskan di dalam Roma 3:25, 5:9, 1 Yohanes $2: 2 ; 4: 10$, berguna sebagai pengganti nyawa umat percaya, yang melalui kematian-Nya menyelamatkan kita dari kemarahan dan penghakiman Allah (1 Tes. 1:10). Demikianlah Allah yang mendekonstruksi (destruksi), pada saat yang sama juga menjadi Allah yang mengkonstruksi dan mendamba hadirnya keutuhan ciptaan. Kerinduan dan motif terdalam yang mengatasi semuanya adalah penyelamatan umat-Nya. Di dalam cinta-Nya yang merengkuh dan menyelamatkan, kemarahan-Nya ada dalam rangkulan kemurahan-Nya. 
Secara paradoks, kemarahan Allah sebagai "righteous anger" pada gilirannya memungkinkan diri-Nya untuk memurkai diri-Nya sendiri, sebagaimana pernyataan Karl Rahner bahwa: "The death of Jesus as the death of God in the sense that through his death 'our death' (becomes) the death of the Immortal God himself" (Moltmann, ebook 2015: 4 dari 172).

Kesemuanya dilakukan-Nya "supaya kita semua menjadi satu, sama seperti Allah Bapa di dalam Yesus Kristus, dan Yesus Kristus di dalam Allah Bapa” (Yoh. 17:21). Jalan untuk kembali kepada terang kesatuan terdapat di dalam cinta; cinta Allah kepada manusia melalui Yesus, cinta manusia kepada Allah melalui Yesus, dan cinta kita kepada sesama satu sama lain melalui Yesus, "This love is the divine unity, reaching out in power and in beauty to make all creation one with God" (Countryman, 1987: 108).

\section{TEOLOGI KEMURAHAN ALLAH MELAMPAUI OPOSISI BINER}

Benarlah pernyataan populer Rudolf Otto perihal Allah Sang Misteri yang senantiasa menakutkan (karena murka-Nya), sekaligus menarik (karena kemurahan-Nya), kendati pada akhirnya kemurahan Allah harus dihayati sebagai yang melampaui segala sesuatunya sebab kemarahan Allah terhisap di dalam kemurahan-Nya. Terhadap hermeneutika yang menjustifikasi kemarahan Allah sebagai alat guna melanggengkan kekerasan dan peperangan, sebagaimana misalnya penggunaan kitab Yoshua yang dijadikan rujukan pengesah bagi laku kolonialisasi di Afrika, Amerika Latin, Amerika Utara, Palestina, maka gereja sebagai pengemban theology of joymeminjam terminologi Moltmann — harus bekerja keras dalam meluruskannya atau mengajukan counter interpretasi alternatif, mengingat sebagaimana Hofgeismar message: "The Bible must not be utilized to justified oppression or supply simplistic commentary on contemporary events, thus sacralizing the [Israeli-Palestinian] conflict and ignoring its socio-political, economic, and historical dimensions" (Lorke dan Werner [eds.], 2013: 268-269).

Di tengah konteks kemalangan dan penderitaan Indonesia, teologi kemurahan layak untuk ditempatkan sebagai daya dukung yang mendorong penguatan solidaritas dan persaudaraan sejati, supaya umat tidak mudah tergiring menjadi pelaku yang gemar menuding serta mempersetankan liyan sembari bertepuk tangan manakala sesamanya tertimpa kemalangan. Demikian pula tatkala umat dihambat, dikorbankan, dilontari api amarah, dan mesiu kebencian, maka semangat kemurahan Allah kiranya memampukan supaya tidak begitu saja tergelincir dalam laku reaktif sekaligus eskapis, melainkan semakin menjadi "minoritas kreatif”-meminjam istilah Notohamidjojoyang terus-menerus berjuang keras mencari jalan guna merengkuh sesama demi keutuhan ciptaan. 
Hermeneutic of suspicion, baik pula digunakan sebagai piranti untuk terus-menerus memeriksa diri, supaya di balik setiap tafsiran religius dan laku eksegese gerejawi yang menelurkan kebijakan kiranya selalu dapat merefleksikan kemurahan Allah.

Dengan mengimplementasikan teologi kemurahan Allah, maka kita akan dimungkinkan untuk berujar sebagaimana Cynthia Bourgeault yang menegaskan bahwa “oposition is not the problem” dan menghargai peranan the denying force (Bourgeault, 2013: 39, 206). Bagaimanapun juga hanya teologi kemurahan Allah yang memiliki daya untuk menguatkan kita dalam menyahabati lawan. Walaupun konsekuensi praktisnya memang tidak selalu mudah. Secara praktis bagaimanakah cara menyikapi sahabat yang mencederai "virtue" yang harusnya dijunjung tinggi? Lumrahnya ketika nilai-nilai yang kita junjung tinggi diinjak-injak, maka sahabat pun secara terbalik akan segera dilihat sebagai musuh bukan? Begitu pula halnya dengan implikasi terhadap dialog interfaith yang memunculkan pertanyaan, "Mungkinkah merangkul, sebutlah kaum fundamentalis-fanatis seperti ISIS dan semacamnya, yang secara diametral sengaja memilih nilai yang berkebalikan dengan kebenaran, kebaikan, dan keindahan?" Tatkala kita berniat baik mengetuk pintu dan mengulurkan genggaman tangan, namun pintu tidak dibuka dan malah dibalas dengan kepalan tangan, bukankah artinya oposisi masih menjadi sebuah kenyataan yang sekaligus berarti menjadi masalah? Bagaimanapun juga, pola oposisi biner yang menegaskan garis demarkasi dan menggelorakan perang antara "yang dianggap gelap" atau "yang diklaim setan" melawan "yang dianggap terang" atau "yang diklaim malaikat," telah menjadi keniscayaan yang secara tak terelakkan mewarnai kehidupan.

Mengimplementasikan teologi kemurahan Allah berarti bergerak melampaui oposisi biner. Jika berhenti pada oposisi biner, maka siklus peperangan yang melelahkan tanpa henti akan terus terjadi. Manusia dengan mengatas-namakan Tuhan akan selalu memerangi dan mengusir mereka yang diklaim sebagai "setan". Sementara mereka yang distigmatisasi sebagai "setan" akan terusmenerus bergerilya menebar teror, mengincar manusia seperti singa berkeliling mengaum-aum mencari manusia yang dapat ditelannya. Demi mengatasinya, teologi kemurahan Allah sebagai "kekuatan ketiga" yang mengedepankan intensi reconciling atau neutralizing harus diberlakukan. Melalui teologi kemurahan Allah yang mengedepankan cinta kasih yang melingkupi segalanya, pada gilirannya dapat mengemuka the new transformative arising.

Saya akan memberikan contoh konteks internal kekristenan di Indonesia menyoal polemik LGBT yang merujuk surat pastoral Persekutuan Gereja-Gereja di Indonesia (PGI), tanggal 17 Juni 2016, bernomor surat 360/PGI-XVI/2016, ${ }^{2}$ kepada seluruh pimpinan gereja di Indonesia. Di dalam pengantar suratnya, PGI menyatakan bahwa pertimbangan-pertimbangan yang ada dalam pernyataan pastoral tidaklah dimaksudkan untuk menyeragamkan, melainkan sebuah ajakan kepada gereja-gereja untuk lebih lanjut mendalami masalah tersebut. Keberanian PGI 
untuk menyuarakan sikap yang jelas demi menegaskan harkat martabat ciptaan Allah yang harus dihargai serta keragaman ciptaan, layak untuk diapresiasi. Di dalam poin pertama, diungkapkan bahwa: "Manusia adalah gambar dan citra Allah yang sempurna. Manusia memiliki harkat dan martabat yang harus dijunjung tinggi." Lalu dalam poin kedua diuraikan bahwa, "Allah menciptakan manusia, makhluk, dan segala ciptaan yang beraneka ragam dan berbeda-beda." Lantas PGI menyarankan untuk, "Bersikap positif dan realistis dalam keanekaragaman... serta mendatangkan kebaikan bagi umat manusia, bagi segala makhluk dan bagi bumi." Menariknya, di dalam poin kelima, PGI menyatakan bahwa: "Keberadaan manusia dengan kecenderungan LGBT merupakan sebuah fenomena yang ada sejak masa lalu. LGBT bukan produk kebudayaan modern, bukan juga produk kebudayaan Barat. Fenomena LGBT ini ada dalam masyarakat kita dan secara sosio-antropologis LGBT ini sudah sejak dulu diakomodasikan dalam budaya beberapa suku di dalam masyarakat kita.” Dan ketika menguraikan apa kata Alkitab, PGI menegaskan bahwa:

\footnotetext{
“Apa yang Alkitab kritisi adalah perilaku seksual yang jahat dan eksploitatif yang dilakukan oleh siapa pun, termasuk yang dilakukan kaum heteroseksual, atau yang selama ini dianggap 'normal'. Pesan utama cerita penciptaan Adam dan Hawa (Kejadian 1:26-28; 2:18, 21-24) misalnya, adalah tentang cikal bakal terjadinya institusi keluarga dan bahwa manusia diberi tanggung jawab untuk memenuhi dan memelihara bumi. Cerita ini sama sekali tidak ditujukan untuk menolak keberadaan kaum LGBT" (PGI, 2016: 2).
}

Kemudian PGI menunjukkan bahwa terdapat interpretasi terhadap ayat-ayat di dalam Alkitab yang tidak tepat jika digunakan untuk menghakimi, menyerang, mendiskriminasi, ataupun menyerang kaum LGBT:

\footnotetext{
“... Alkitab mengkritisi dengan sangat keras ibadah agama kesuburan (menyembah Baal dan Asyera, Hakim-hakim 3:7; 2 Raja-raja 23:4) oleh bangsa-bangsa tetangga Israel pada masa itu, yang mempraktikkan semburit bakti yaitu perilaku seksual sesama jenis sebagai bagian dari ibadah agama Baal itu (Ulangan 23:17-18); demikian juga terhadap penyembahan berhala Romawi di zaman Perjanjian Baru (Roma 1:2332)... Bagian-bagian ini tidak ditujukan untuk menyerang, menolak, atau mendiskriminasi kaum LGBT" (PGI, 2016: 2).
}

Menurut PGI, apa yang ditolak dalam teks-teks Alkitab adalah segala jenis perilaku seksual yang jahat dan eksploitatif yang dilakukan oleh siapa pun atas dasar apa pun, termasuk dasar agama, dan ditujukan terhadap siapa pun, termasuk terhadap perempuan, laki-laki, dan anak-anak. Kemudian sesudah merujuk pada Pedoman Penggolongan dan Diagnosis Gangguan Jiwa di Indonesia edisi II tahun 1983 dan edisi III tahun 1993, yang menyebutkan bahwa LGBT bukan penyakit kejiwaan, maka PGI dalam poin 9-11 memberikan rekomendasi yang mengajak gereja-gereja sebagai keluarga Allah dan persekutuan inklusif untuk menerima, membela, dan memperjuangkan hak LGBT sebagai bagian utuh dari tubuh Kristus. 
Segera setelah diedarkan, surat pastoral PGI memantik protes keras. Komunitas XBTNetwork Pekanbaru misalnya, dalam surat yang dikeluarkan pada Rabu, 29 Juni 2016, mendesak MPH PGI untuk mencabut pernyataan pastoral tentang LGBT dan meminta maaf secara terbuka kepada sinode/ gereja/umat Kristen Indonesia, bahkan mengancam jika dalam waktu satu bulan terhitung sejak dikeluarkannya pernyataan pastoral tentang LGBT, MPH PGI tidak segera mencabut dan meminta maaf, maka menyerukan pembentukan forum penyelamatan PGI dan menginisiasi tindakan disiplin organisasi terhadap ketua umum dan sekretaris umum, sebab pesan pastoral dituding berpotensi menimbulkan konflik dan kebencian, baik di internal Kristen maupun umat beragama lain yang secara tegas menolak perilaku LGBT. ${ }^{3}$ Sinode Gereja Bethel Indonesia (GBI) juga melayangkan protes, karena sebagai anggota PGI, GBI merasa tidak diajak untuk berdiskusi, padahal GBI telah terlebih dahulu menyatakan sikap terhadap LGBT dengan menegaskan bahwa perilaku LGBT adalah dosa dan menentang pernikahan sesama jenis, walaupun di sisi lain GBI menyerukan bahwa setiap orang dengan perilaku LGBT harus dikasihi dan ditolong untuk keluar dari penyimpangan tersebut. ${ }^{4}$

Saya sepakat dan mendukung penghargaan terhadap kaum LGBT sebagai bagian dari mengupayakan keutuhan ciptaan, walaupun pernyataan pastoral yang digagas MPH PGI lebih mencerminkan semangat kaum sofis yang memantik kontroversi. MPH PGI justru menjadi affirming factor yang secara oposisional berhadap-hadapan dengan denying factor, yang salah satunya direpresentasikan oleh Sinode GBI sebagai anggota PGI. Idealnya, sebagai payung, tidak bijak jika MPH PGI begitu saja larut dalam polemik pro atau kontra LGBT, karena ketika memilih salah satu, maka berarti mengeksklusikan atau meminggirkan yang lain. Dalam pengantar suratnya, MPH PGI mengungkapkan bahwa kesadaran akan sikap dan ajaran gereja sangatlah beragam sehingga surat pastoral tidak dimaksudkan untuk menyeragamkan. Pernyataan tersebut baik, walau faktanya, di dalam butir uraian penjelasan, tendensi menggiring ke arah penyeragaman sikap untuk menerima LGBT dengan balutan sikap pastoral terasa kuat gemanya, dan kontan memicu gelombang protes dari gereja-gereja yang menolak LGBT. PGI dianggap tidak lagi menjadi payung yang merengkuh kepelbagaian.

Teologi kemurahan Allah tidak bisa dilepaskan dari prinsip merengkuh. MPH PGI memang berupaya memperlihatkan kemurahan Allah dengan mendukung LGBT, namun ia abai dengan prinsip merengkuh. Prinsip merengkuh berarti berkomitmen untuk hidup dalam rekonsiliasi, hidup dalam solidaritas dengan mereka yang miskin-terpinggirkan, menyelamatkan yang terbelenggu derita, menghargai mereka yang berbeda, menghidupi "passion for unity," mempromosikan dialog dan kolaborasi, bertanggung jawab dalam turut menghadirkan kualitas kehidupan yang jauh lebih baik bagi keluarga umat manusia, serta bergantung pada Cinta Bapa sebagaimana Yesus yang bergantung pada Bapa-Nya. Keberpihakan MPH PGI terhadap LGBT telah mengakomodasi 
semangat menghargai yang berbeda, solidaritas, dan upaya menyelamatkan yang terbelenggu derita. Namun, sayangnya dimensi dialog dan kolaborasi, serta menghidupi "passion for unity" belum ditampakkan, dan mengeksklusikan suara penolakan dari GBI sebagai anggota bernaung di dalam institusi PGI. Supaya relasi kembali utuh, maka teologi kemurahan Allah yang mengejawantah dalam rengkuhan, perlu dihidupkan dengan cara kembali fokus dalam ranah artikulasi substansi nilai yang terkandung dalam misi dan tujuan gereja, ketimbang sibuk menceburkan diri dalam polemik. Upaya semacam ini diperlihatkan oleh World Council of Churches ketika misalnya dalam dokumen Together towards Life tidak pernah sedikit pun menyebut isu LGBT atau perkawinan sejenis secara eksplisit, namun secara substansial justru menegaskan keharusan gereja untuk membela setiap orang yang termarjinalkan, seperti diungkapkan dalam poin 107: “... We must turn our direction of mission to the actions that the marginalized are taking. Justice, solidarity, and inclusivity are key expressions of mission from the margin” (Keum, 2013). Jika misalnya MPH PGI gagap melakukannya, maka lembaga pendidikan teologi, gereja-gereja, ataupun asosiasi persekutuan gereja lainnya menurut hemat saya dapat berinisiatif menghadirkan teologi kemurahan Allah yang merekonsiliasi dan merangkul perbedaan.

Bagaimanapun juga, menyoal sesama yang enggan membuka pintu rumahnya, maka laku yang harus diupayakan tanpa kenal menyerah adalah tetap mencintainya tanpa henti, tanpa tepi, apa pun yang terjadi, mengingat teologi kemurahan Allah memiliki intensi untuk menyatakan sukacita sejati dan mengejawantahkan kedamaian hakiki demi kesatuan dan kepenuhan segala sesuatunya dengan Sang Pengada.

\section{Catatan}

1 The multiplex method merupakan preferensi Osborne setelah mencermati pelbagai metodologi yang terbentang mulai metode sintetik, analitik, sejarah, diakronik dan kritik tradisi, christological, hingga metode konfesional. Dalam multiplex, kekuatan dari masing-masing metode dikombinasikan, serta memberi tempat bagi teks untuk sepenuhnya membimbing. Terdapat lima kriteria yang sekaligus menjadi kontrol atasnya: (1) Data harus merepresentasikan keragaman tema dan genre. (2) Bentuk dokumen yang final dari kanon-lah yang harus dipergunakan, supaya tidak terjatuh pada rekonstruksi spekulasi kritik historis, dan interrelasi antara tema dengan kitab harus dicari. (3) Terdapat dua tugas; mendeskripsikan dan menganalisa kepelbagaian tema biblikal individual, kemudian menyatukannya satu sama lain. (4) Mempelajari tema individual dan menjelajahi kesatuan tema/discovery of unyfing themes. (5) Produk akhirnya harus mengintegrasikan kitab-kitab, baik diversity maupun unity (Osborne, 1991: 277-281).

${ }^{2}$ http://pgi.or.id/wp-content/uploads/2016/06/Pernyataan-Sikap-PGI-tentang-LGBT.pdf

3 https://reformata.com/news/view/1470/pgi-dituntut-untuk-segera-mencabut-pesan-pastoral-terkait-lgbt

4 https://www.jawaban.com/read/article/id/2016/06/27/91/160628112557/sinode_gbi_akan_protes_ke_pgi_ terkait_pesan_pastoral_tentang_lgbt 


\section{DAFTAR PUSTAKA}

Bourgeault, Cynthia. 2013. The Holy Trinity and the Law of Three: Discovering the Radical Truth at the Heart of Christianity. Boston \& London: Shambhala Publications.

Campbell, Alastair V. 1986. The Gospel of Anger. London: SPCK.

Countrymann, L. William. 1987. The Mystical Way in The Fourth Gospel: Crossing Over into God. Philadelphia: Fortress Press.

Craigie, Peter C. 1981. The Problem of War in The Old Testament. Grand Rapid, Michigan: William B. Eerdmans Publishing Company.

Garbini, Giovanni. 1988. History and Ideology in Ancient Israel, translation John Bowden. Great Britain: SCM Press.

Osborne, Grant R. 1991. The Hermeneutical Spiral, a Comprehensive Introduction to Biblical Interpretation. Illionis: InterVasity Press.

Karman, Yonky. 2007. Bunga Rampai Teologi Perjanjian Lama. Jakarta: BPK Gunung Mulia.

Keum, Jooeseop (ed.). 2013. "Together towards Life: Mission and Evangelism in Changing Landscape-with Practical Guide." WCC Publication.

Lorke, Melisande dan Werner Dietrich (ed.). 2013. Ecumenical Visions for the $21^{\text {st }}$ Century: A Reader for Theological Education. Geneva: WCC Publications.

Mojau, Julianus. 2012. Meniadakan atau Merangkul? Pergulatan Teologis Protestan dengan Islam Politik di Indonesia. Jakarta: BPK Gunung Mulia.

Moltmann, Jurgen, 2015. The Crucified God, 40 $0^{\text {th }}$ Anniversary Edition. Minneapolis: Fortress Press.

PGI, MPH. 2016. “Pernyataan Sikap PGI Tentang LGBT”, June 17, 2016.

Yong, Amos. 2008. Hospitality and The Other, Pentecost, Christian Practices, and The Neighbor. New York: Orbis Books. 